$\left[\begin{array}{c}\text { J.M.J., Vol. 4, No. 4] } \\ \text { August, } 1951\end{array}\right]$

\title{
ON THE ANTIGENICITY OF DIPHTHERIA TOXOID. \\ PART II. PRELIMINARY REPORT ON THE IMMUNIZING POTENCY OF DIPHTHERIA TOXOID FRACTIONS ISOLATED AT LOWER AMMONIUM SULFATE CONCENTRATION
}

\author{
MASAMI KUROKAWA, RYOSUKE MURATA, TAKESHI NAKANO, \\ TAKAKO YAMADA AND KENTARO KUBOTA
}

The National Institute of Health, Tokyo, Japan

\section{INTRODUCTION}

In the preceding paper ${ }^{1)}$, Kurokawa and others scrutinized several methods for the measurement of immunizing potency of diphtheria toxoid, which have generally been used hitherto, and deviced one method or two for precise measurement which suit for routine use in laboratories, because of their comparative accuracy and less expenses. On the basis of the results thus acquired, Kurokawa and others are performing the analytical studies on the factors participating in the immunizing potency of diphtheria toxoid.

In the studies on the methods for the measurement of immunizing potency in the preceding paper, several kinds of highly purified toxoid were used as the experimental materials. These highly purified toxoids were fractions precipitated between 30 per cent and 60 per cent saturation with ammonium sulfate. These fractions did not seem to denature during the process of purification, but it appeared to be so sensitive in vivo that the immunizing potency was markedly affected by the diluent used for injection.

While the fraction precipitated at 30 per cent saturation with ammonium sulfate, designated as " $30 \%$ fraction" in this paper, is generally discarded in the process of purification, the nature of the " $30 \%$ fraction" in respect to the immunizing potency seems not to have been reported yet.

This paper concerned with some properties of fractions of this type isolated at low ammonium sulfate concentrations.

\section{EXPERIMENT}

A material, $\mathrm{AFr}_{30}$ II, isolated at the 30 per cent saturation with ammonium sulfate during the course of preparation of highly purified toxoid 
No. II, designated as $\mathrm{AFr}_{30-60}$ II in this paper, was flocculated so slowly with antitoxin that the Lf value was obtained only by means of the blended method. Examining with the methods deviced in the preceding paper, the immunizing potency of this fraction was evidently lower than that of $\mathrm{AFr}_{30-60}$ II (groups A and B, Table 1). However, when equal dose of $\mathrm{AFr}_{30}$ II and $\mathrm{AFr}_{30-60}$ II in terms of Lf was mixed, the $\mathrm{Kf}$ of the mixture

Table 1.

Immunizing potency of a fraction isolated at a low ammonium sulfate concentration. (1)

\begin{tabular}{|c|c|c|c|c|c|c|c|c|}
\hline \multirow[b]{2}{*}{ Groups } & \multirow{2}{*}{$\begin{array}{r}1) \\
\text { Samples }\end{array}$} & \multirow{2}{*}{\begin{tabular}{|l} 
Lf \\
dosis \\
inoc.
\end{tabular}} & \multirow{2}{*}{$\mathrm{Kf}^{2)}$} & \multicolumn{2}{|c|}{ Antitoxin unit $/ \mathrm{ml}$} & \multicolumn{2}{|c|}{ Challenge test } & \multirow{2}{*}{$\begin{array}{l}\text { Date of } \\
\text { toxoid } \\
\text { inoculation }\end{array}$} \\
\hline & & & & $\begin{array}{l}\text { average } \\
\text { titer }\end{array}$ & $\begin{array}{c}\text { animal: } \\
\text { tested }\end{array}$ & $\begin{array}{l}\text { Lest } \\
\text { does }\end{array}$ & $\begin{array}{l}\text { survived } \\
\text { trested }\end{array}$ & \\
\hline A. & $\begin{array}{cc}\text { A.R. } & 9-60 \\
\text { dil. } & \text { II } \\
\text { I } & 40\end{array}$ & 24. & $80(24)$ & 0.168 & (5) * & & $0 / 5$ & \\
\hline B & $\begin{array}{c}\operatorname{AFr}_{30} \\
\text { dil. }\end{array}$ & 22 & $\stackrel{\S}{8}$ & 0.014 & (6) * & 1000 & $0 / 5$ & $\begin{array}{l}28 / \text { Sep. } \\
1950\end{array}$ \\
\hline $\mathrm{C}$ & $\begin{array}{l}\mathrm{AFr}_{0-60} \mathrm{II} \\
+\mathrm{ANr}_{0} \mathrm{II}\end{array}$ & 47 & $70(47)$ & 0.185 & (6) & & $2 / 5$ & \\
\hline D & $\begin{array}{c}\mathrm{AFr}_{30-60} \text { II } \\
\text { dil. } \\
1: 50\end{array}$ & 21 & & 0.024 & $(9) *$ & 100 & $1 / 9$ & 30/Oct. \\
\hline $\mathbf{E}$ & $\begin{array}{l}\text { A.Fr } r_{: 0} \text { II } \\
\text { dil. } 1: 50\end{array}$ & 21 & & 0.003 & $(12) *$ & & $8 / 12$ & 1950 \\
\hline
\end{tabular}

1) ATr $\mathrm{r}_{: 0-60}$ II: " highly purified toxoid II" in the previous paper, $\mathrm{Lf}=1080, \quad \mathrm{Kf}_{30}=150, \quad \mathrm{~N} / \mathrm{Lf}=0.00048 \mathrm{mg}, \quad$ purity $=95 \%$.

$\mathrm{AFr}_{30}$ II : $\quad \mathrm{Lf}=300-350, \quad \mathrm{~N} / \mathrm{Lf}=0.00227-0.00195 \mathrm{mg}, \quad \mathrm{Kf}=\infty$

Method of preparation as follows,

Toxoid prepared from the infusion-free pepton broth

Precipitated with: zine chloride

Eluted with phosphate buffer

Precipitated at $30 \%$ sat. with am. sulfate

Ppt.

Dissolved with phosphate; buffer

Supernatant

Repeat of precipitation with ammonium sulfate and resolution

$$
\mathrm{AFr}_{30} \text { II }
$$

A.F $\mathbf{r}_{30-60}$ II

2) § indicates to have been performed by means of the blended method.

3 ) * indicates that difference of average titers is significant at the $5 \%$ level of risk (between $\mathrm{A}$ and $\mathrm{B}, \mathrm{D}$ and $\mathrm{E}$ respectively). 
thus obtained was larger than that of $\mathrm{AFr}_{30-60}$ II and Lf was equal to the sum of each fraction and the immunizing potency did not seem to fluctuate from that of $\mathrm{AFr}_{30-60}$ II (group $\mathrm{C}$, Table 1). In other words, it seemed to be more rational to consider that the toxoid itself contained in $\mathrm{AFr}_{30}$ II is different in respect to the immunizing potency from the toxoid contained in $\mathrm{AFr}_{30-60}$ II, rather than that there are something else, but not toxoid, affecting the immunizing potency of the toxoid contained in the fraction.

Immunizing potencies of $\mathrm{AFr}_{30}$ II and $\mathrm{AFr}_{30-60}$ II were compared again and the same result was obtained (groups $\mathrm{D}$ and $\mathrm{E}$, Table 1). Immunizing potencies of other materials, $\mathrm{AFr}_{25} \mathrm{IV}, \mathrm{AFr}_{30-35} \mathrm{IV}$ and $\mathrm{AFr}_{35-60} \mathrm{IV}$, prepared from another crude toxoid, preparation method of which was described in Table 2, were compared and it was observed that the fractions precipitated at lower concentrations of ammonium sulfate had evidently lower potency (Table 2).

However, the means of antitoxin titer of groups $\mathrm{D}$ and $\mathrm{E}$ in Table 1 and of all groups in Table 2 were evidently lower than that of groups A, $\mathrm{B}$ and $\mathrm{C}$ and that observed in the similar experiments performed in our laboratory hitherto. The test toxin used in the measurement of antitoxin titer was the same and no significant variation of the test dose was observed throughout the whole experiments. And, in each animal, the relation between the antitoxin content of blood and the tolerance to toxin, subcutaneously (Table 1 and 2) or intracutaneously (Table 2) injected, coincided with the results described in the preceding paper. ${ }^{1)}$ Therefore, unusually low titers of antitoxin above described do not seem to be due to procedure of titration. In this respect, it may be of special interest to describe that the experiments of groups $\mathrm{A}, \mathrm{B}$ and $\mathrm{C}$ in Table 1 , groups $\mathrm{D}$ and $\mathrm{E}$ in Table 1 and groups in Table 2 were performed during the period from the end of September to the end of October, during the period of the end of October to the end of November, and during the period of January and February respectively, and that the other experiments performed in the identical manner during the same period also showed similar tendency (Table 3). Though several reports that the antitoxin response of animals was influenced by season have been published, 2 ) this problem will be described in a separate paper. In this paper, only the results obtained during the same period were compared each other.

The ratios of total Lf of fraction precipitated at the 30 per cent saturation to total Lf recovered were found to range from less than 10 per 
Table 2.

Immunizing potency of fractions isolated at low ammunium sulfate concentrations. (2)

\begin{tabular}{|c|c|c|c|c|c|c|}
\hline \multirow[b]{2}{*}{ Groups } & \multirow{2}{*}{ Samples } & \multirow{2}{*}{$\begin{array}{l}\text { Lf } \\
\text { dosis } \\
\text { inoc. }\end{array}$} & \multirow{2}{*}{$\mathrm{Kf}$} & \multicolumn{2}{|c|}{ Antitoxin unit $/ \mathrm{ml} \quad 3$ ) } & \multirow{2}{*}{$\begin{array}{c}\text { Date of } \\
\text { toxoid } \\
\text { inoculation }\end{array}$} \\
\hline & & & & $\begin{array}{c}\begin{array}{c}\text { average } \\
\text { titer }\end{array} \\
\end{array}$ & $\begin{array}{c}\text { animals } \\
\text { tested }\end{array}$ & \\
\hline A & $\mathrm{AFr}_{25} \mathrm{IV}$ & 20 & $420+120(25) \S$ & 0.0004 & $(5) * * *$ & \\
\hline B & $\mathrm{AFr}_{: 0-5} \mathrm{IV}$ & 20 & $145 \quad(25) \S$ & 0.004 & $(6) *$ & 17/Jan. 1951 \\
\hline C & $\mathrm{AFr}_{35-60}$ IV & 20 & $150 \quad(15) \S$ & 0.012 & (5) & \\
\hline
\end{tabular}

1) Method of preparation as follows:

Toxoid prepared from Martin broth

Precipitated with zine chloride

Eluted with sodium phosphate

Precipitated at $30 \%$ saturation with ammonium sulfate

Precipitate Supernatant

Dissolved with aq. dest.

Precipitated at $20 \%$ saturation

with ammonium sulfate

Precipitate Supernatant

Precipitated at $25 \%$ saturation with am. sul.

Precipitate Supernatant

AFr. IV Precipitation at $30 \%$ saturation

Precipitate

Precipitated at $35 \%$ saturation with ammonium sulfate

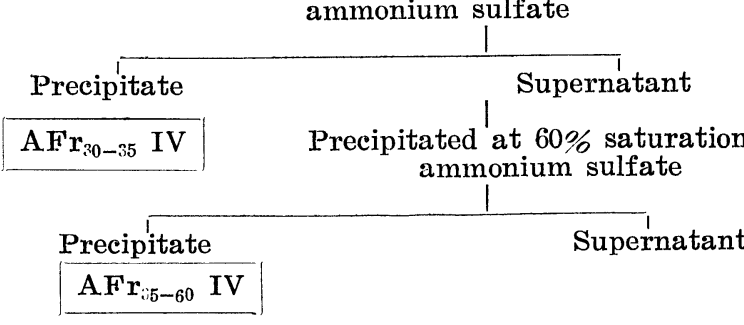

2) § indicates to have been performed by means of the blended method.

3) ${ }^{* *}$ indicates that difference of average titers is significant at the $5 \%$ level of rick between $\mathrm{A}$ and $\mathrm{B}, 1 \%$ between $\mathrm{A}$ and $\mathrm{C}$, respectively. 
cent to more than 50 per cent for various kinds of toxoid preparation, crude or partially purified, manufactured by various plants in our country. The conditions increasing this radio during the process of purification or detoxification and the role played by these fractions in immunizing potency of toxoid are still under investigations. As an instance showing the relation between the immunizing potency and the ratio of total Lf of " $30 \%$ faction" to total Lf recovered, one of the experiments performed in respect to this problem was shown in Table 3, by which it seems, in most cases at least, that there exists a tendency which the more the " $30 \%$ fraction" is contained in toxoid, the less the the immunizing potency of toxoid becomes. Moreover, from Table 3, it seems that the condition causing the $\mathrm{Kf}$ increase may be another factor responsible for the discrepancy between the Lf value and the immunizing potency in vivo.

Table 3.

Immunizing potency of serveral toxoid preparations.

\begin{tabular}{|c|c|c|c|c|c|c|c|}
\hline \multirow{2}{*}{ Toxoids } & \multirow{2}{*}{$\begin{array}{l}\text { Lf } \\
\text { dosis } \\
\text { injec. }\end{array}$} & \multirow{2}{*}{$\mathrm{Kf}$} & \multicolumn{2}{|c|}{$\begin{array}{l}\% \text { of total Lf of fractions } \\
\text { to total Lf recovered }\end{array}$} & \multirow{2}{*}{\multicolumn{2}{|c|}{ Antitoxin $\mathrm{u} / \mathrm{ml}$}} & \multirow{2}{*}{$\begin{array}{l}\text { Surviaval } \\
\text { rate } \\
(10 \mathrm{MLD})\end{array}$} \\
\hline & & & $30 \%$ frac. & $30-60 \%$ frac. & & & \\
\hline C & 13 & $60(36)$ & 6 & 94 & 0.007 & (7) & $7 / 7$ \\
\hline $\mathrm{K}$ & 12 & $220+50 *$ & 9 & 91 & & & $4 / 9$ \\
\hline O & 16 & $130(33)$ & 15 & 85 & & & $11 / 11$ \\
\hline $\mathrm{U}$ & 27 & $40(55)$ & 17 & 83 & & & $7 / 9$ \\
\hline $\mathrm{R} 1$ & 13 & $\infty$ & 17 & 83 & & & $3 / 7$ \\
\hline $\mathrm{D}$ & 15 & $90(30)$ & 19 & 81 & 0.003 & (8) & $5 / 6$ \\
\hline A & 7.5 & $\infty$ & 20 & 80 & & & $0 / 9$ \\
\hline$F$ & 18 & $190(37)$ & 40 & 60 & 0.002 & (9) & $5 / 8$ \\
\hline $\mathrm{R} 2$ & 13 & $130(26)$ & 40 & 60 & & & $6 / 10$ \\
\hline Q1 & 30 & $90(60)$ & 50 & 50 & 0.001 & (9) & $2 / 7$ \\
\hline I & 11 & $450(22)$ & 66 & 34 & & & $1 / 10$ \\
\hline Q2 & 27 & $90(54)$ & 68 & 32 & 0.001 & (9) & $1 / 8$ \\
\hline
\end{tabular}

* Flocculation appeared after it was left standing overnight in cold chamber.

The results described hitherto in this paper seem to give one of the bases for interpretation of nature of diphtheria toxoid in respect to immunizing potency or for selection of method of purification, and further, a part of discrepancy between the Lf value and the immunizing potency in vivo may be explained by them. It may be interesting to recall in this respect that Pappenheimer $^{3}$ ) and Agner ${ }^{4}$ noted that diphtheria toxin 
precipitated at low ammonium sulfate concentration was flocculated very slowly and possessed low toxicity per Lf unit.

\section{SUMMARY}

The immunizing potency of the fractions of diphtheria toxoid precipitated at lower ammonium sulfate concentrations were evidently lower than that of fractions precipitated at higher ammonium sulfate concentrations.

\section{REFERENCES}

(1) Kurokawa, M., Murata, R. Nakano, K., Yamada, T. and Kubota, K.: On the antigenicity of diphtheria toxoid. Part I. Jap. Med. J., 4, 1951.

(2) Glenny, A. T. and Waddington, H.: The immunity index method of testing antigenic value. J. Path. Bact., 31, 403-421, 1928.

Schmidt, S•: Ueber die Einwirkung von Formaldehyd auf Diphtheria Toxin. II. Die Immunisierende Eigenschaft der Anatoxine. Z. Immunitätsf., 78, 323-339, 1933.

Prigge, R.: Theorie und Methodik der Anligenmessung. Z. Hyg., 119, 186$192,1937$.

Cameron, G.D.W.: Seasonal variation in response of guinea pigs to toxoid. Canad. Publ. Hlth. J., 29, 500-503, 1938.

(3) Pappenheimer, A. M.: Diphthrietoxin. I. Isolation and characterization of a toxoid protein from Corynebacterium diphtheriae filtrate. J. Biol. Chem., 120, 543-533, 1937.

Pappenheimer, A.M.: Studies of a diphtheria toxin and its reaction with antitoxin. J. Bact., 43, 373-553, 1942.

(4) Agner, K.: Studies of peroxidative detoxification of purified diphtheria toxin. J. Exp. Med., 92, 337-347, 1950. 